\title{
Commentary \\ Meeting the Mental Health Needs of College Student-Mothers during the COVID-19 Pandemic in the United States
}

\author{
Kobi V. Ajayi ${ }^{1,2,3}$ \\ 1 Department of Health and Kinesiology, Texas A\&M University, College Station, TX 77843, USA; \\ omo_debare@tamu.edu \\ 2 Laboratory for Community Health Evaluation and Systems Science (CHESS), \\ Department of Health and Kinesiology, Texas A\&M University, College Station, TX 77843, USA \\ 3 Education, Direction, Empowerment, \& Nurturing (EDEN) Foundation, Abuja 900001, Nigeria
}

Citation: Ajayi, K.V. Meeting the Mental Health Needs of College Student-Mothers during the COVID-19 Pandemic in the United States. Women 2021, 1, 137-142. https://doi.org/10.3390/ women1030013

Academic Editor: Mary V. Seeman

Received: 16 July 2021

Accepted: 25 August 2021

Published: 27 August 2021

Publisher's Note: MDPI stays neutral with regard to jurisdictional claims in published maps and institutional affiliations.

Copyright: (C) 2021 by the author. Licensee MDPI, Basel, Switzerland. This article is an open access article distributed under the terms and conditions of the Creative Commons Attribution (CC BY) license (https:/ / creativecommons.org/licenses/by/ $4.0 /)$.

\begin{abstract}
The coronavirus (COVID-19) pandemic is the deadliest public health emergency in the twenty-first century. To mitigate the rapid spread of the virus, institutions around the globe, including higher education, instituted infection control measures such as social distancing and restricted movements with virtual/remote work and learning environments. These changes, including the pandemic-related stressors, are associated with poor mental health among college students. However, student-mothers may encounter an aggravated psychological impact of the pandemic because of their competing and challenging intersecting roles. Multipronged strategies and targeted-mental health services that consider the needs of student-mothers, their children, and families are encouraged to mitigate the pandemic's impact. Doing so has important implications for public health, policy, and research.
\end{abstract}

Keywords: student-mothers; COVID-19; mental health; college students

\section{Introduction}

The coronavirus (COVID-19) pandemic is the deadliest public health emergency in the twenty-first century. To mitigate the rapid spread of the virus, institutions around the globe, including higher education, instituted infection control measures such as social distancing and restricted movements. In response, higher education transitioned from traditional face-to-face activities to virtual/remote work and learning environments. These changes, including the pandemic-related stressors (e.g., personal loss, unemployment, misinformation regarding the COVID-19 and the vaccine, and worries for personal safety), are associated with poor mental health among college students [1,2].

Although college students are particularly vulnerable to the psychological sequelae of the pandemic, gender disparities exist [1,2]. For example, Lopez-Castro and colleagues [2] assessed the mental health of 909 students from the City University of New York (CUNY) using validated psychological assessment tools. This study found that women had significantly higher scores of depression, anxiety, and stress than men. Taken together, female college students are at increased risk of poor mental health than their male counterparts. However, it is plausible that female students who are raising children will experience a magnified effect of the pandemic on their mental health and overall academic success because of their competing and intersecting roles as mothers, students, and employees.

This commentary aims to describe the potential mental health impact of the pandemic on mothers who are raising children in institutions of higher education. Due to the limited, albeit non-existent literature investigating this narrative, this paper draws inferences from existing literature investigating the pandemic's impact on the mental health among college students, women, and women faculties with children amid the COVID-19 pandemic to inform future research, policy, and practice for student mothers and subsequently the student-parent population. 


\section{Methods}

In a commentary, researchers seek to present new ideas and perspectives while also mapping future directions to a particular topic of interest [3]. Accordingly, this commentary utilized a non-systematic approach to retrieve relevant articles from PubMed and Google Scholar. Key search terms unique to each section were used to identify relevant articles for each section discussed in this submission. Therefore, this submission is outlined thus: overview of student-mothers in higher education, mental health of student-mothers before the COVID-19 pandemic, maternal mental health amidst the pandemic, mental health of faculty mothers during the pandemic, the relationship between mental health and educational status, recommendations, and conclusion.

\section{Overview of Student-Mothers in Higher Education}

According to the Institute for Women's Policy Research, more than one in five undergraduate students are raising children in the United States [4]. Women represent more than $70 \%$ of the overall student-parent population, and approximately $62 \%$ are single. Compared to non-parent female students, student mothers encounter significant hardships to their degree attainment, putting them at risk of not completing their education. For example, single mothers have higher dropout rates, with only $28 \%$ earning a degree within six years than $57 \%$ of female students without children [5].

For student-mothers, access to education is a guaranteed means to workforce participation, thereby decreasing the risk of poverty. Women earn higher wages as they attain higher levels of education. For example, women with a complete four-year degree make roughly $\$ 23,000$ more than those with less than a higher education degree [6]. Thus, postsecondary education is an effective safety net to secure mothers' economic and financial well-being. Unfortunately, policies and programs within and outside higher education do not adequately meet student-mothers' needs, exacerbating their vulnerabilities [4-6].

Student-mothers experience substantial barriers to their degree attainment that are unique and multifaceted. Issues related to unaffordable on-campus childcare centers, time conflicts, school-work-parenting balance, quality housing, lack or inadequate oncampus policies aimed at pregnant or student-parents, financial constraints, and other socioeconomic barriers are persistent barriers to completing a post-secondary education for student-mothers [4,5]. Furthermore, structural barriers such as the Child Care Means Parents in School Program (CCAMPIS) - the only federal program covering childcare costs for low-income women in higher education, is substantially underfunded. In the 2016-2017 school years, CCAMPIS provided childcare tuition for about 4000 students, but almost 4200 were waitlisted [7].

\section{Mental Health of Student-Mothers before COVID-19}

Pre-COVID-19, extensive research has shown that student-parents have poorer mental health than their non-student-parent counterparts. Student-mothers often report feeling isolated and marginalized not only by their peers but by faculty/staff and the school environment as a whole [8]. Racial/ethnic minority student-mothers-Blacks and Hispanics who represent most of the student-parent population-also report being discriminated against and judged for their life choices by society $[4,8]$. However, some have described feeling guilty, stressed, anxious, and depressed from balancing their conflicting roles [8]. In addition, student-mothers experience maternal mental health illnesses such as postpartum depression and/or anxiety, which can lead to suicide [9]. If these patterns hold, then it appears that the COVID-19-related changes to learning (e.g., virtual/remote learning in colleges and K-12), strained social network, and other pandemic-related stressors combined with everyday schooling challenges will adversely affect the mental health of student-mothers than other student subgroups. 


\section{Evidence of Poor Mental Health among Mothers in COVID-19}

Abundant research has shown that women have suffered the most from the pandemic than men [10-13], with some describing the pandemic as gendered. The reasons for the disproportionate impact of the pandemic on women are not far-fetched. For example, the stay-at-home order gave rise to remote/virtual work and schooling environments for families and students. As such, elevated caregiving burdens rested more on the mothers' shoulders, who have to continue working and/or schooling and assumed the roles of "school teachers" for their children while also taking care of the day-to-day activities of the home. Women also accounted for more job losses, with some deliberately opting out of the workforce to care for their families [11]. However, while caregiving burdens have increased for women, these roles are unpaid, further increasing existing gender gaps and socioeconomic inequalities [11]. These unfavorable socioeconomic conditions are likely to magnify the risk of depression and anxiety in women and mothers who are already vulnerable to poor mental health. In their review of 7750 women, Hessami and colleagues [13] found a significant increase in anxiety (State-Trait Anxiety Inventory STAI; SMD $=0.82,95 \%$ CI: 0.49-1.16) during than before the pandemic. Another study by Davenport and colleagues [13] assessed the prevalence of depression and anxiety among pregnant $(n=520)$ and new mothers $(n=380)$ between April and May 2020 using the Edinburgh Postnatal Depression Survey (EPDS) and STAI score. In this study, elevated levels of depression (EPDS score > 13) were found in $40.7 \%$ of the women during the pandemic vs. $15 \%$ pre-pandemic. In addition, changes in obstetric guidelines and birth plans and worries about contracting the virus and its effect on the fetus among birthing people are associated with being stressed, worried, or anxious [14]. Moreover, maternal mental health disorders lead to negative lifelong consequences for mothers, infants, and families $[12,13]$. Thus, addressing maternal mental health amidst the pandemic is of utmost importance to achieving health equity.

\section{Evidence of Poor Mental Health and Productivity among Mothering Faculty in COVID-19}

In discussing the psychological impact of the pandemic on student-mothers, it is important to highlight a similar yet different group of mothers within the higher education ecosystem-women faculty who are mothers. Indeed, student-mothers and mothering faculty experience similar challenges related to childcare, although often with reduced stigma. However, mothering faculties are more likely to have the resources to afford structural advantages than student-mothers. For example, it is expected that faculties earn more than students, which may moderate the pandemic's impact. Yet, whereas much research exists investigating the pandemic impact on mothering faculty, limited research exists for student-mothers.

Nonetheless, since the pandemic, mothering faculties have experienced disproportionate productivity across several productivity metrics and increased mental health burdens than men [15]. A combination of several factors may explain this productivity gap. One study comprising 117 mothering faculty with diverse academic positions found that $48 \%$ were primarily responsible for childcare than only $5 \%$ of their partners. In addition, $51 \%$ of the mothers were mostly responsible for their children's schooling relative to $5 \%$ of their partners [16]. Notably, gender differences have been reported in manuscript development and research, with women faculties reporting decreased productivity, whereas productivity for male faculty remained stable [17]. The adverse consequences of productivity gaps, e.g., non-tenure, combined with the pandemic-related stressors discussed earlier, may be associated with depression and anxiety among faculty mothers and not fathers. In a recent study, Docka-Filipek and Stone [18] analyzed job-related factors on faculty mental health during the initial "stay-at-home-orders" using the self-reported 10-item Center of Epidemiologic Studies Depression scale (CES-D). In this study, gender was a significant predictor of elevated depressive and anxiety symptoms, further exacerbated by having a higher teaching load, the number of dependents at home, and financial concerns among women 
faculty. Notably, this study found that female faculty assumed more non-career advancing responsibility (e.g., administrative tasks) than males, accounting for productivity gaps in research or career advancement.

Considering the substantial hardship the pandemic has wrought on mothering faculty, who are less socioeconomically vulnerable than student-mothers, it is clear that studentmothers will experience severe negative consequences of the pandemic on their mental health and academic success.

\section{The Relationship between Education and Mental Health}

There is a strong association between education and adult mental health. Higher educational level improves individual skills, promotes positive health behaviors, benefits from structural advantages, and empowers coping methods [19]. Educational level is also associated with earning and labor force participation [7]. Collectively, these factors can promote mental health. However, there is a causal link between poor mental health and educational attainment. For example, a study of mothers with children in an Early Head Start program found that women with depression often do not increase their participation in educational activities, job training, or employment [20]. Because education is inherently associated with mental health and vice versa, protecting student-mothers mental health during and after the pandemic is necessary to secure their economic and financial security. Moreover, the benefit of protecting the mental health of student-mothers transcends beyond achieving academic success but into closing existing social and economic inequalities with intergenerational benefits. This is because student-mothers view their educational achievement as a means of modeling future career possibilities for their children and families [8].

\section{Charting a Way Forward}

There is an urgent need for higher education to establish strategies to protect the mental health and well-being of student-mothers not just during but also beyond the pandemic. First, higher education should ensure an inclusive campus environment by providing targeted mental health services for student-mothers. Student-mothers need services that speak to their unique needs; however, services available in higher education are often exclusionary, focusing on non-traditional students (i.e., students who transition to higher education immediately after high school) who are often not parenting or working full time. For instance, the CUNY Accelerated Study in Associate Programs (ASAP) program is an excellent program that can be modified to meet the mental health needs of student-mothers [21]. Providing targeted mental health services and counseling require concerted and deliberate efforts from policymakers and academic administrators by allocating resources to create and sustain such programs and services. In light of the psychological sequelae of the pandemic, meeting student-mothers where they are by integrating maternal mental health care and family therapy programs into the existing institutional mental health service is a step in the right direction to protect their academic success, mental health, and well-being. Moreover, inclusive mental health services in higher education will also benefit parenting faculty and staff regardless of sex and gender.

Secondly, higher education should provide flexible class schedules and on-campus childcare centers' operating hours for student-mothers to enable them to balance their conflicting roles. One approach to achieve this may be for higher education to retain or integrate aspects of remote learning (e.g., asynchronous learning) in place since the pandemic, where possible. A flexible system that helps these students manage their schedules may likely reduce stress from missed classes or assignments while increasing quality time spent with their families. Such systems can be especially essential for single student-mothers, who are saddled with parenting responsibility alone, to learn at a suitable pace, likely reducing dropout rates and consequently increasing academic retention overall.

Thirdly, higher education should create mechanisms to keep abreast of the unique challenges student-mothers encounter, be aware of their unique situation and be proactive 
in addressing potential barriers to their academic pursuit and overall well-being. For instance, processes should be put in place to identify and connect student-mothers (and not on a case-by-case basis) with available on-campus services (e.g., student services department, parenting workshops) and off-campus community resources that provide social services (e.g., faith-based groups, parenting workshops, the Special Supplementary Nutrition Program for Women, Infants, and Children, etc.) [22]. Because most studentmothers are socioeconomically disadvantaged, connecting them to social services can contribute greatly to ameliorate financial stressors.

Fourthly, promoting interventions that target major stressors experienced by women is critical. For example, bereavement programs can be adapted through a student-parent lens to offer emotional support to mothers who have lost loved ones or are experiencing economic hardship due to COVID-19 [11]. Such programs could also be useful for mothers experiencing pregnancy loss or other obstetric challenges. Amidst the pandemic, providing such services may help lessen the pandemic's psychological implications on women. Lastly, as the world gradually returns to "normal" and higher education transition to traditional face-to-face learning, there is the possibility that mothers will be anxious about returning to their pre-pandemic lifestyle as such, higher education should establish targeted mentoring/advising with individuals (e.g., parenting faculties) familiar with the situations of this population.

It is imperative to acknowledge that although these recommendations are geared towards student-mothers, they could also be applied to student-fathers, parenting faculty/staff, or other populations in higher education tasked with caregiving burdens of disabled or elderly parents or siblings.

\section{Conclusions}

Student-mothers encounter unparalleled stressors to their degree attainment, which is exacerbated by the pandemic. Considering that the pandemic has disrupted academic experience, student engagement and caused high dropout rates, higher education must pay heightened attention to meeting the needs of student-mothers and other vulnerable student subgroups. Student-mothers deserve access to equitable services to secure their academic success. As such, academic administrators should foster an inclusive campus environment and establish multipronged strategies through a student-parent lens. Doing so has important implications for public health, policy, and social justice.

Funding: The author received no financial support for the research, authorship, and/or publication of this article.

Institutional Review Board Statement: Not applicable.

Informed Consent Statement: Not applicable.

Data Availability Statement: Not applicable.

Conflicts of Interest: The author declared no potential conflicts of interest with respect to the research, authorship, and/or publication of this article.

\section{References}

1. Gazmararian, J.; Weingart, R.; Campbell, K.; Cronin, T.; Ashta, J. Impact of COVID-19 Pandemic on the Mental Health of Students from 2 Semi-Rural High Schools in Georgia. J. Sch. Health 2021, 91, 356-369. [CrossRef] [PubMed]

2. Lopez-Castro, T.; Brandt, L.; Anthonipillai, N.; Espinosa, A.; Melara, R. Experiences, impacts and mental health functioning during a COVID-19 outbreak and lockdown: Data from a diverse New York City sample of college students. PLoS ONE 2020, 16, e0249768. [CrossRef]

3. Berterö, C. Guidelines for writing a commentary. Int. J. Qual. Stud. Health Well-Being 2016, 11, 31390. [CrossRef] [PubMed]

4. Cruse, L.R.; Holtzman, T.; Gault, B.; Croom, D.; Polk, P. Parents in College By the Numbers. IWPR 2020. Available online: https:/ /iwpr.org/iwpr-issues/student-parent-success-initiative/parents-in-college-by-the-numbers/ (accessed on 23 June 2021 ).

5. Kruvelis, M.; Cruse, L.R.; Gault, B. Single Mothers in College: Growing Enrollment, Financial Challenges, and the Benefits of Attainment. IWPR 2020. Available online: https:/ /iwpr.org/iwpr-issues/student-parent-success-initiative/single-mothers-incollege-growing-enrollment-financial-challenges-and-the-benefits-of-attainment/ (accessed on 22 June 2021). 
6. Bureau of Labor Statistics, U.S. Department of Labor, The Economics Daily. Educational Attainment and Earnings of Women. Available online: https:/ /www.bls.gov/opub/ted/2014/ted_20140603.htm (accessed on 24 August 2021).

7. United States Government Accountability Office. Higher Education More Information Could Help Student Parents Access Additional Federal Student Aid. 2019. Available online: https:/ / www.gao.gov/assets/710/701002.pdf (accessed on 22 June 2021).

8. Sealey-Ruiz, Y. Learning to resist: Educational counter-narratives of Black college reentry mothers. Teach. Coll. Rec. 2013, 115, 1-31.

9. Roy, R.N.; Bradecich, A.; Dayne, N.; Luna, A. The Transition to Motherhood: The Experiences of College Student-Parents. J. Fam. Consum. Sci. 2018, 110, 48-57. [CrossRef]

10. Alzueta, E.; Perrin, P.; Baker, F.C.; Caffarra, S.; Ramos-Usuga, D.; Yuksel, D.; Arango-Lasprilla, J.C. How the COVID-19 pandemic has changed our lives: A study of psychological correlates across 59 countries. J. Clin. Psychol. 2020, 77, 556-570. [CrossRef] [PubMed]

11. Foxwell, A.M.; Kennedy, E.E.; Naylor, M. Investment in Women's Mental Health During and After the COVID-19 Pandemic. J. Women's Health 2021, 30, 918-919. [CrossRef] [PubMed]

12. Hessami, K.; Romanelli, C.; Chiurazzi, M.; Cozzolino, M. COVID-19 pandemic and maternal mental health: A systematic review and meta-analysis. J. Matern. -Fetal Neonatal Med. 2021, 1-8. [CrossRef] [PubMed]

13. Davenport, M.H.; Meyer, S.; Meah, V.L.; Strynadka, M.C.; Khurana, R. Moms are not OK: COVID-19 and maternal mental health Front. Glob. Women's Health 2020, 1, 1. [CrossRef]

14. Ajayi, K.V.; Harvey, I.S.; Panjwani, S.; Uwak, I.; Garney, W.; Page, R.L. Narrative Analysis of Childbearing Experiences during the COVID-19 Pandemic. MCN Am. J. Matern. Child Nurs. 2021, 46, 284-292. [CrossRef]

15. Guy, B.; Arthur, B. Academic motherhood during COVID-19: Navigating our dual roles as educators and mothers. Gend. Work Organ. 2020, 27, 887-899. [CrossRef] [PubMed]

16. Kasymova, S.; Place, J.M.; Billings, D.L.; Aldape, J.D. Impacts of the COVID-19 pandemic on the productivity of academics who mother. Gend. Work Organ. 2021, 28, 419-433. [CrossRef] [PubMed]

17. Krukowski, R.A.; Jagsi, R.; Cardel, M.I. Academic Productivity Differences by Gender and Child Age in Science, Technology, Engineering, Mathematics, and Medicine Faculty During the COVID-19 Pandemic. J. Women's Health 2021, 30, 341-347. [CrossRef] [PubMed]

18. Docka-Filipek, D.; Stone, L.B. Twice a 'housewife': On academic precarity, 'hysterical' women, faculty mental health, and service as gendered care work for the 'university family' in pandemic times. Gend. Work Organ. 2021. [CrossRef]

19. Halpern-Manners, A.; Schnabel, L.; Hernandez, E.M.; Silberg, J.L.; Eaves, L.J. The Relationship between Education and Mental Health: New Evidence from a Discordant Twin Study. Soc. Forces 2016, 95, 107-131. [CrossRef]

20. Schmit, S.; Walker, C. Seizing New Policy Opportunities to Help LowIncome Mothers with Depression: Current Landscape, Innovations, and Next Steps. Available online: https:/ /www.clasp.org/sites/default/files/public/resources-and-publications/ publication-1/Opportunities-to-Help-Low-Income-Mothers-with-Depression-1-1.pdf (accessed on 22 June 2021).

21. Levin, H.M.; García, E. Accelerating Community College Graduation Rates: A Benefit-Cost Analysis Accelerating Community College Graduation Rates: A Benefit-Cost Analysis. J. High. Educ. 2018, 89, 1-27. [CrossRef]

22. Ajayi, K.V.; Ma, P.; Akinlotan, M. COVID-19 and the Vulnerability of Single Mothers in Institutions of Higher Education. Fam. Community Health 2021, 44, 235-237. [CrossRef] 